\title{
A Survey Study: The Correlation between Metacognitive Strategies and Reading Achievement
}

\author{
Sukris Sutiyatno \\ STMIK Bina Patria Magelang, Central-Java, Indonesia \\ Sukarno \\ Universitas Tidar (UNTIDAR) Magelang, Central-Java, Indonesia
}

\begin{abstract}
The aim of this research is to reveal the effect of metacognitive strategies on students' reading achievement. The research employed a quantitative approach with survey research. The data of metacognitive strategies were collected by means of questionnaires and scores of reading achievement used test. The data were analyzed by using correlation product moment $(r)$. The finding of the research showed that the coefficient correlation of Product Moment $(r)=0.721$ with the sig. $0.000<0.05$ and explained that there was a correlation between metacognitive strategies and reading achievement of undergraduate students. The result of the research implied that the students should increase the understanding of metacognitive deeper to help them understand English text books better.
\end{abstract}

Index Terms—a survey study, metacognitive strategies, reading achievement

\section{INTRODUCTION}

The strategies that teachers often use to support the students in figuring out how they learn many kinds of skills in the learning environment are metacognitive strategies. It can encourage the learners in deciding how they implement the thinking process (Oxford, 2013). Rationally, these processes will make students understand their own capabilities. Further, the teachers mostly apply it in order to push the learners to be strategic thinkers. It helps in influencing the brain process that supports individuals in overcoming various routine problems. It can also involve a scientific approach that can help in the assessment of one's thought processes. Although metacognitive regulation helps to direct the learning process, students should be set open to various teaching methods (Azevado \& ALeven, 2013). After realizing one's knowledge, students are able to manage their mind processes in many ways but always within the curriculum outputs.

Louca (2003) illustrates metacognition as cognition about cognition because it entails examining the brains' processing during the process of thinking. Reading as a cognitive process explains indirectly that metacognition during the process of reading could direct to better comprehension. Then, Iwai (2011) declares that metacognition plays an essential role in reading comprehension since it is related to the development of linguistic, cognitive, and social skills. During reading comprehension, "the process of metacognition is explained through strategies which have characteristics such as procedural, purposeful, effortful, willful and essential and facilitative" (Alexander \& Jetton, 2000).

Meanwhile, Reading comprehension is determined as the grade of analysing a text which comes from the relation between the words that are written and how they trigger knowledge outside the text. It would be difficult to study a foreign language without learning this skill (Jafari \& Ketabi, 2012). To implement strategies of metacognitive, readers are classified into two categories; skilled readers and unskilled ones (Pressley \& Afflerbach, 1995). Skilled readers apply one or more metacognitive strategies to analyze the texts effectively and to promote their capability in this regard.

Steinbach (2010) investigates the metacognition strategies skills like planning, problem-solving, monitoring effectiveness, self-assessment, self-correction and evaluation with the view of progress. During learning students have the awareness of using these processes involved in metacognitive strategies. Then, Shah (2012) contended that students in many institutions depend on these strategies to realize better academic achievement. In addition, Zohar \& Dori (2012) described that these strategies will push them in understanding what they understand about social studies, what they should do, what they have studied and whatever they can do to improve on what they have acquired.t

Metacognition means thinking about what one is doing while reading (Pressley, 2002). Metacognition plays an essential role in students' learning, Graham (1997) explains that metacognitive strategies that make students able to plan, control and examine their learning are more crucial than strategies that increase interaction and input. Metacognitive strategies can construct something more than an inclination towards cooperation, namely self- esteem and selfconfidence given by the skill to select and evaluate the strategies of one's learning, moreover the value of each strategy and the independence in studying that keeps up with them (Boghian, 2016, p.55). 
The implementation of metacognitive approaches, for instance, self-monitoring or awareness helps in improving selflearners who have the capability to plan on their studies for the rest of their learning process. This links to the selfguidance that the process inculcates in the lives of such learners. Through this, metacognition improves and develops learning experiences in the given field of study. Through the improvement of learning experiences, learners are capable of achieving better problem-solving and learning skills. Metacognitive strategies encourage learners to analyse their development of learning and thus provide good guidance (Herrera, Holmes \& Kavimandan, 2011).

\section{LITERATURE REVIEW}

The term 'meta-cognitive thinking', meta-knowledge, thinking about thinking' and 'awareness of thinking' is used synonyms for 'meta-cognition', which, in turn, means one's awareness of their cognitive progress, mental activities as well as learning and self-techniques that are used in learning, understanding, planning, management and problem solving (Ersolu \& Arslan, 2009). Metacognition is a basic concept of cognitive psychology that "emphasize the responsive participation of the individual in his or her process of thinking" (Stewart \& Landine, 1995, p.17). Meanwhile, Belet et. al. (2011) confirmed that the meta-cognitive thinking links to one's awareness of thinking, and the processes they make use in different learning situation so that they can analyse and control thinking, make knowledge construction active and easy, and use their abilities to manage, organize, plan, modify cognitive behaviour. Teachers' emotional behavior and emphaty, their ability to show understanding for their students' feelings and actions, plays a very important role in making the teaching learning process more comfortable and successful (Sutiyatno, 2018, p. 431).

Then, Edwards, et al. (2014) explain that knowledge of metacognition is the consciousness to one's thinking processes. It refers to a process through which individuals realize their processes of thought. Hopefully, learners who have awareness of metacognitive strategies understand what to do when they don't know what to do; that is, they have strategies for understanding what they need to do. Metacognitive strategies can ignite one's thinking and can direct to much deeper learning and improved performance, especially among learners who are struggling. Understanding and managing cognitive processes can be one of the most crucial skills that teachers can conduct students to increase their achievement. Vagle (2009) puts metacognitive thinking at the peak level of mental activity since it keeps individual aware of themselves and others during the process of thinking to overcome the problems.

Cohen \& Dornyei (2002) describe that metacognitive strategies indicate to "those processes which learners consciously use in order to monitor their language learning, 'which' permit learners to lead their own cognition by designing what they will do, evaluating how it is going and then examining how it went'. Briefly, strategies of metacognitive are acting upon what you know-i.e. directing, improving, increasing etc. what you know. Clegg (2015, p.4-5) suggests a synthetic presentation of metacognitive, cognitive and social-effective learning strategies. We will present and describe them further because we trust that they are all relevant for language learning and also because the cognitive and social-affective strategies support the building and formation of metacognitive skills.

The crucial reason as to why most educationists utilize metacognitive approaches in education correlating to the instant impact it has on the students (Bentahar, 2012). Metacognitive knowledge contributes to students in reflecting on what they are thinking or what they already understand. The consciousness of knowledge also contributes to the students in understanding what they do not understand (Cohen, 2014). Then, the awareness of metacognitive can push the students to make improvement in their ways of dealing with the difficult elements of learning. For example, students may make the decision to develop their shortcuts in overcoming the problems (Mclnerney, 2013).

Meanwhile, Khezrlou (2012, p.50) explained that when reading in order to analyse a text, learners use a variety of strategies that may be: (1) cognitive: guessing, translating, summarizing, linking with earlier knowledge or experience, using grammar rules, guessing meaning from text, (2) metacognitive: self-evaluation, planning, monitoring one's process of learning The process of metacognition is implemented by using strategies, which are "procedural, purposeful, effortful, willful, essential, and facilitative in nature" during reading (Alexander \& Jetton, 2000, p.295). Through metacognitive strategies, a reader provides with serious attention controlling, monitoring, and evaluating the reading process (Pressley, 2000; Pressley et al., 1995).

Proficient readers apply one or more metacognitive strategies to analyse the text. The application of strategies has grown over time as the reader studies which ones are best related to contribute in comprehension (Pressley, WhartonMcDonald, Mistretta-Hampston, \& Echevarria, 1998). Tierney (2005) states that learning to read is not only learning to understand words; it is also learning to make sense of texts. Successful language learners must have the ability to supervise, evaluate, and control their thinking (Koda, 2007).

Metacognition is an essential characteristic of effective reading and reading instruction (Israel, 2007, p.1), so is metacognitive consciousness of the reading strategies one uses. In particular, the strategies of reading used by the readers, their metacognitive consciousness, and reading proficiency are very closely correlated. Essentially, successful readers use more strategies compared to less successful students and use them more frequently. Meanwhile, Sahin (2011) infers that meta-knowledge strategies are complex intellectual skills that are taken into consideration the essential factors of smart behaviour for processing information.

Brown (2004, p.185) explains that reading means skill that teachers simply hope the learner to acquire, basic, beginning-level textbooks in a foreign language. Reading, debatably the most crucial skill for successful achievement in all educational contexts remains a skill of great importance. In addition, Taraban \& Rynearson (2004, p.69) declares 
that college students select and apply reading strategies that are focused on success in academic achievement. Reading has been a crucial position in either second language teaching or foreign language teaching and plays an essential role in improving the students' English proficiency.

\section{RESEARCH METHOD}

This research has made use of quantitative approach with the correlational method. Correlational research involves data collection to decide whether, and to what degree, a relationship is available between two or more quantitative variables. The correlational method has two major objectives: (1) to know the relationship between variables and (2) to predict the score on a variable from subjects' scores on other variables (Borg \& Gall, 1989, p.577).

The technique of data analysis in this research used the product moment correlation coefficient, usually related to as the Pearson $r$. This analysis was used to predict the degree of relationship of Independent variable-- metacognitive strategies on dependent variable-- the reading achievement of the students.

The research population is the third year students of English Department of UNTIDAR Magelang that consists of 121 students with the sample of 55 students

\section{RESUlts AND DisCUSSION}

\section{A. Description of the Research Data}

Descriptive Statistics
\begin{tabular}{|l|l|l|l|l|l|}
\hline & $\mathrm{N}$ & Minimum & Maximum & Mean & Std. Deviation \\
\hline SCORES & 55 & 35.00 & 93.00 & 82.6000 & 9.30472 \\
METACOGNITIVE & 55 & 67.00 & 132.00 & 108.4182 & 14.12863 \\
GLOBAL READING & 55 & 27.00 & 59.00 & 46.9455 & 6.65949 \\
STRATEGIES & & 16.00 & 35.00 & 29.0364 & 3.90139 \\
\hline $\begin{array}{l}\text { PROBLEM-SOLVING } \\
\text { STRATEGIES }\end{array}$ & 55 & 21.00 & 40.00 & 32.4364 & 4.13998 \\
$\begin{array}{l}\text { SUPPORT READING } \\
\text { STRATEGIES }\end{array}$ & 55 & & & & \\
Valid N (listwise) & 55 & & & & \\
\hline
\end{tabular}

The instrument of metacognitive reading strategies of the respondents used the Survey of Reading Strategies (SOARS) questionnaire which was developed by Mokhtari \& Sheorey (2002). The items of the questionnaire consisted of three sub-categories: Global Reading Strategies (GLOB), Problem-Solving Strategies (PROB), and Support Reading Strategies (SUP).

\section{B. Result and Discussions}

\section{Result}

The Relation of Metacognitive Strategies on Students' Reading Achievement

\begin{tabular}{|c|c|c|c|c|c|c|}
\hline \multicolumn{7}{|c|}{ Correlations } \\
\hline & & SCORES & METACOGNITIVE & $\begin{array}{l}\text { GLOBAL READING } \\
\text { STRATEGIES }\end{array}$ & $\begin{array}{l}\text { PROBLEM SOLVING } \\
\text { STRATEGIES }\end{array}$ & $\begin{array}{l}\text { SUPPORT READING } \\
\text { STRATEGIES }\end{array}$ \\
\hline \multirow[t]{3}{*}{ SCORES } & $\begin{array}{l}\text { Pearson } \\
\text { Correlation }\end{array}$ & 1 & $721^{* * k}$ & & & \\
\hline & Sig. (2-tailed) & & .000 & .000 & .000 & .000 \\
\hline & $\mathrm{N}$ & 55 & 55 & 55 & 55 & 55 \\
\hline
\end{tabular}

Based on table 1 above the coefficient correlation of Product Moment (r) $=0.721$ with the sig. $0.000<0.05$ explain s that there is a correlation between metacognitive strategies and reading achievement of the undergraduate students. Meanwhile, the result of analysis from three sub-categories of metacognitive strategies; Global Reading Strategies (GLOB) has coefficient correlation of 0.769 with the sig. $0.000<0.05$, Problem Solving Strategies (PROB) has coefficient correlation of 0.620 with the sig. $0.000<0.05$ and Support Reading Strategies (SUP) has coefficient correlation of 0.638 with sig. $0.000<0.05$. Among the three subcategories, Global Reading Strategies (GLOB) has the biggest correlation on the students' reading achievement.

\section{Discussion}

The result of the analysis explains that there is a correlation between metacognitive strategies and students' reading achievement, This finding of research is in line with the research of Jafari $(2012$, p. 4) Stating that the result of the research indicates that practising in metacognitive language learning strategies helps learners develop their listening and reading skills and raise their language proficiency. He also declares that the differences between skilled and less skilled readers and reports the strategies of reading, their use of global and reading strategies (such as underlining, guessing, reading twice), their metacognitive awareness, their perception of a good reader, and their self-confidence as readers. 
Ismail \& Tawalbeh (2015) has conducted a quasi-experimental study examining the effect of the strategies of metacognitive reading on EFL low achievers in reading. The study reveals that training on the use of metacognitive strategies among low achieving EFL readers improves reading comprehension performance. Channa, et. al. (2015) reveales that this study will encourage readers to think over metacognitive strategies as the input to construct material of reading comprehension and syllabus based on planning, monitoring, and evaluating strategies of the students to increase reading skills for the learners' better comprehension of the text according to their needs as well as teachers scaffold to improve reading and comprehending abilities of the students.

Better readers have better metacognitive awareness of their own strategy use, which leads to enhanced reading ability (Hamdan et al., 2010, p.135). Then, Boulware-Gooden et. al (2007) evaluate how instruction of metacognitive strategies promote reading comprehension and vocabulary attainments of third-grade students. In addition, Nejad \& Shahrebabaki (2015) reveales that there is a significant positive relationship between the students' metacognitive strategy use and their reading comprehension performance.

Jafari \& Ketabi (2012) have found that the instruction of metacognitive strategy has a positive impact on the desirable noticing of strategy use in terms of awareness-raising. It is very urgent to give more attention that metacognitive strategy instruction encourages learners of EFL to solve their difficulties in reading comprehension and provide the participants with a means of pushing them to develop their reading comprehension.

Research reveals that metacognition is a strong predictor of learning. Metacognitive practices make a particular contribution to learning over and above the effect of intellectual capability. The impact of this research is that developing a student's metacognitive practices can recompense for any cognitive restrictions they may possess (Veenam \& Wilhelm, \& Beishuizen, 2004; Wang, Haertel \& Walberg, 1990).

Estacio (2013) declares that it is revealed that the application of the metacognitive reading strategies is a means of reading comprehension achievement predictor. Hustre (2011) also explains if metacognitive reading strategies can act as a predictor of text comprehension and she reveales that problem-solving strategies have a positive impact on reading comprehension.

In addition, students who have effective reading strategies can employ in higher thinking skills about texts and their relations to that text (Hernandez-Laboy, 2009, p.4). In other words, strategic readers are very metacognitive and they realized the ongoing of the process of reading and how a text can be difficult (Pressley, Warthon \& Mc Donald, 1997).

Further, a research on metacognition indicates that metacognitive strategy is closely related to success in second/foreign language learning. Learners who are provided with metacognitive strategies, realize their learning and they understand how and when to use the most relevant strategies to complete a given task; they understand how to finish a special task in the most effective strategy. They prepare their learning in advance, supervise their learning during the task performance, and examine their learning after task completion (Zhang \& Goh, 2006).

Meanwhile, learners who apply metacognitive strategies in their learning seem to be more self-regulated learners. Improving learners' self-managed learning and independence have received a good attention and overwhelm educational organizations nowadays. The metacognitive direction is an effective method to increase learner-focused and learner autonomy. Various researches have performed that the direction of metacognitive strategies encourages learners to be more self- regulated, self-discipline and successful in their learning (Goh, 1997; O'Malley \& Chamot,1990; Vandergrift, 2003).

Alshammari (2015) has found that metacognitive strategies help individual students in understanding the learning skills that they are required to have in their classroom. From this study, it is evident that the students with metacognitive strategies develop better learning skills compared to the others without such strategies. Through metacognition, students will be able to receive feedback for learning. This process helps in motivating the learners to develop their skills in learning (Wathen, 2010).

Students using metacognitive strategies are able to learn readily what they expect in order to overcome the academic handicaps that they have as specified (Azevedo \& Aleven, 2013). Meanwhile, Ramdass \& Zimmerman (2008) studied the effects of training students to use metacognitive strategies to improve mathematics achievement. The practices of metacognition have been exhibited to increase academic attainments across a range of ages, cognitive abilities, and learning domain (Dignath, Buettner \& Langfeldt, 2008). Similarly, Hauck (2005) states that learner who has improved their metacognitive understanding are probably to become more autonomous language learners. In addition, Chamot (2005) confirms that unsuccessful language learner does not possess the knowledge of metacognitive required to choose appropriate strategies. Then, Estacio (2013) finds that the metacognitive reading strategies play a role to predict reading comprehension test score

On the contrary, Wallace (2005) has surveyed that in reading classes of EFL, students usually have a little chance to be participating in higher level thinking tasks. Consequently, the students do not study to read comprehensively, nor do they achieve an evaluative understanding of the text as well as improve their critical thinking ability. As a result, learners get disappointed and degraded spirit for independent reading because their classroom tasks do not go beyond sitting and listening to their teacher's long-winded explanations and speeches (Wallace, 2005). Koroteva (2012) explains that the strategies of metacognitive in reading comprehension of education majors and reveales that the respondents performed metacognitive strategy use really ineffectively. 


\section{CONClusions AND SugGestions}

Based on Table 1 above the coefficient correlation of Product Moment $(r)=0.721$ with the sig. $0.000<0.05$ and explains that there is a correlation between metacognitive strategies and reading achievement of undergraduate students. It means that this research revealed that metacognitive strategies have a correlation with students' reading achievement and metacognitive strategies play an important role to improve the students' reading achievement. The result of this research implies that the students should increase the understanding of metacognitive deeper to help them read English text books better.

\section{REFERENCES}

[1] ALshammari, M.K. (2015). The effect of using metacognitive strategies for achievement and the trend toward social studies for intermediate schools students in Saudi Arabia. International Journal of Education, Learning and Development, vol. 3, No. 7, pp. 47-5

[2] Alexander, P.A., \& Jetton, T.L. (2000). Learning from text: A multidimensional and development perspective. In M.L. In M.L. Kamil, P.B. Mosenthal, P.D. Pearson, \& R. Barr (Eds.), Handbook of Reading Research, vol. 3, 285-310

[3] Azevado, R. \& Aleven, V.A.W.M.M. (2013). International handbook of metacognition and learning technologies. New York: Springer

[4] Belet et. Al. (2011). "Metacognitive strategy usage and epistemological beliefs of a primary school teacher", Educational Sciences: Theory \& Practice. 11:1, 51-57.

[5] Bentahar, A. (2012). Can ESL Teachers Teach Reading Metacognitive Strategies?: The case of ESL students struggling with reading comprehension. Saarbrucken: LAP LAMBERT Academic Publishing

[6] Boghian, I. (2016). Metacognitive learning strategies in teaching English as a foreign language. Journal of Innovation in Psychology, Education and Didactics, vol. 20 no. 1 pp (53-62).

[7] Borg, R.W. \& Gall, M.D. (1989). Educational Research: An Introduction. New York: McGraw Hill

[8] Boulware-Gooden, R., Carreker, S., Thornhill, A. \& Joshi, R. (2007). Instruction of metacognitive strategies enhances reading comprehension and vocabulary achievement of third-grade students. Reading Teacher, 61 (1). 70-77.

[9] Brown, H. D. (2004). Language assessment; Principle and classroom practices. New York: Pearson Education

[10] Channa, M, A., Nordin, Z, S., Siming, I, A., Chandio, A, A., \& Koondher, M, A. (2015). Developing reading comprehension through metacognitive strategies: A review of the previous study. Journal of English language Teaching, Vol. 8, No. 8, 2015, 181-186.

[11] Chamot, A. U. (2005). Language learning strategy instruction. Current issues and research. Annual Review of Applied Linguistics, 25, 112-130.

[12] Clegg, J. (2015). Metacognition. An overview of its uses in language learning. Retrieved on June 20 2016 , from http://www.puglia.istruzione.it portofolio_new/allegation/j_clegg_metacognition_an_overview_of_itsuses_in_language_learning,pdf.

[13] Cohen, A., \& Dornyei, Z. (2002). Focus on the language learner: Motivation, styles and strategies. In N. Schmitt (Ed.), AN Introduction to applied linguistics (pp. 170-190).London: Arnold.

[14] Cohen, A.D. (2014). Strategies in learning and using a second language. London: Routledge

[15] Dignath, C., \& Buettner, G., \& Langfeldt, H.P. (2008). How can primary school students learn self-regulated learning strategies most effectively? Educational Research Review, 3, 101-129.

[16] Edwards, A.J., Weinstein, C.E.T., \& Alexander, P.A. (2014). Learning and study strategies: Issues in assessment, instruction, and evaluation. New York: Elsevier

[17] Ersozlu, et. al. (2009). The effect of developing reflective thinking on meta-cognitional awareness at primary education level in Turkey. Reflective Practice, 10(5), 683-695.

[18] Estacio, M.J. (2013). Bilingual readers' metacognitive strategies as predictors of reading comprehension. Philippine ESL Journal, 10, 179-199.

[19] Goh, C. (1997). Metacognitive awareness and second language listener. ELT Journal, 51(4), 361-369. http://dx.doi.org/10.1093/elt/cc1002.

[20] Graham, S. (1997). Effective and cognitive learning. Positive strategies for advanced level language learning. Clevedon, England: Multilingual Matters

[21] Hamdan, A. R., Ghafar, M. N., Sihes, A. J., \& Atan, S.B. (2010). The cognitive and metacognitive reading strategies of foundation course students in Teacher Education Institute Malaysia. European Journal of Social Sciences, 13 (1), 133-144.

[22] Hauck, M. (2005). Metacognitive knowledge, metacognitive strategies and CALL. In J. Egbert \& G. Petrie (Eds.), CALL research perspectives. Mahwah, NJ: Lawrence Erlbaum Associates, 65-86.

[23] Herrera, S.G., Holmes, M., \& Kavimandan, S. (2011). Crossing the vocabulary bridge: Differentiated strategies for the diverse secondary classroom. New York: Teachers College Press.

[24] Hernandez-Laboy, O.I. (2009). Reading strategies ESL teachers utilize to enhance comprehension in students; Implication for classroom practices. Dissertation presented to the Department of Graduate Studies College of Education University of Puerto Rico

[25] Hustre, C. A. (2011). Belief about reading, metacognitive strategies and text comprehension among college students at a private university. Philippine ESL Journal, 7 (July 2011), 28-47.

[26] Ismail, N. M., \& Tawalbeh, T. L. (2015). The effectiveness of a metacognitive reading strategies program for improving low achieving EFL readers. International Education Studies, 8(1), 71-81.

[27] Israel, S.E. (2007). Using metacognitive assessments to create individualized reading instruction. Newark, DE: International Reading Association. 
[28] Israel, S. E. (2007). Thinking metacognitively. Using metacognitive assessment to create individualized reading instruction. Newark, DE: International Readin Association

[29] Iwai, Y. (2011). The effects of metacognitive reading strategies: Pedagogical implication for EFL/ESL teachers. The Reading Matrix, 11 (2), 150-157.

[30] Jafari, D., \& Ketabi, S. (2012). Metacognitive strategies and reading comprehension enhancement in Iranian Intermediate EFL setting. International Journal of Linguistics Vol. 2 (3), 1-14.

[31] Khezrlou, S. (2012). "The relationship between cognitive and metacognitive strategies, age and level of education". The Reading Matrix, 12 (1), 50-61.

[32] Koda, K. (2007). Reading and language learning: Crosslinguistic, constraints on second language reading development. Language Learning, 57 (1), 1-44.

[33] Koroteva, I, V. (2012). Metacognitive strategies in reading comprehension of education majors. Procedia-Social and Behavioral Science, 69 (2012), 18951900.

[34] Louca, E, P. (2003). The concept and instruction of metacognition. Teacher Development, 7 (1), 9-30.

[35] Mclnerney, D. M. (2013). Educational Psychology: Constructive learning. Person: Higher Education AU.

[36] Mokhtari, K., \& Sheorey, R. (2002). Measuring ESL students reading strategies. Journal of Development Education, 25 (3), 2 10.

[37] Monsakorn, N. (2012). Awareness of reading strategies among EFL learners at Bangkok University. International Journal of Social Behavior, Educational, Business and Industrial Engineering, 6 (5), 821-824.

[38] Nejad, B, S., \& Shahrebabaki, M, S. (2015). Effects of metacognitive strategy instruction on the reading comprehension of English language learner through the Cognitive Academic Language Learning Approach (CALLA). International Journal of Languages' Education and Teaching, 3 (2), 133-164.

[39] O’Malley, J. M., \& Chamot, A. U. (1990). Learning strategies in second language acquisition. Cambridge: Cambridge University Press

[40] Oxford, R. L. (2013). Teaching \& Researching: Language Learning Strategies. New York: Routledge

[41] Pressley,M., \& Afflerbach,P. (1995). Verbal protocols of reading: The nature of constructively responsive reading. Hillsdale NJ: Erlbaum

[42] Pressley, M., Wharton-McDonald, R. (1997). Skilled comprehension and its development through instruction. School Psychology Review, 26 (3), 448-466.

[43] Pressley, M, Wharton-McDonald, R.Mistretta-Hampston, J., \& Echevarria, M. (1998). The nature of literacy instruction in ten grade-4/5 classrooms in upstate New York. Scientific Studies of Reading, 2, 159-194.

[44] Pressley, M. (2002). Metacognition and self-regulated instruction. In A. Farstrup \& S. Samuels (Eds.). What research has to say about reading instruction ( $3^{\text {rd }}$ ed., pp. 291-309). Newark, DE: International Reading Association

[45] Ramdass, D., 7 Zimmerman, B. J. (2008). Effects of self-correction strategy training on middle school's self-efficacy, selfevaluation, and mathematics division learning. Journal of Advanced Academics, 20, 18-41.

[46] Sahin, A. (2011). Evaluating pre-service Turkish teacher's reflective thinking tendencies according to various variables. Electronic Journal of Social Sciences. 10(37), 108-119.

[47] Shah, S.T. (2012). Examining the impact of selected metacognitive strategies on learning. UMI. Second Edition

[48] Steinbach, J.C. (2010). The effect of metacognitive strategy instruction on writing. Lexington: First Edition.

[49] Stewart, J., \& Laudine, J. (1995). Study skills from a metacognitive perspective. Guidance \& Counseling, 11, 16-20.

[50] Sutiyatno, S. (2018). The effect of teacher's verbal communication and non-verbal communication on students' English achievement. Journal of Language Teaching and Research. Vol.9 (2) March 2018, 430-437.

[51] Taraban, R., Kerr, M \& Rynearson, K. (2004). Analytic and pragmatic factors In college students' metacognitive reading strategies. Reading Psychology, 25, 67-81, 2004.

[52] Tierney, J, E. (Ed.). (2005). Reading strategies and practices $\left(6^{\text {th }}\right.$ ed). Boston: Pearson Education

[53] Vagle, Mark (2009). "Locating and exploring teacher perception in the reflective thinking process", Teacher and Teaching. 15:5, 579-599.

[54] Vandergrift, L. (2003). From prediction through reflection: Guiding students: Through the process of L2 listening comprehension. Canadian Modern Language Review, 59(3), 425-440. http://dx.doi.org/10.3138/cmlr.59.3.425.

[55] Veenman, M.V.J., Wilhelm, P., \& Beishuizen, J.J. (2004). The relation between intellectual and metacognitive skills from a development perspective. Learning and instruction. 14, 89-109.

[56] Wallace, C. (2005). Critical reading in language education. EFL Journal, 59 (3), 187-188.

[57] Wang, M.C., Haertel, G.D., \& Walberg, H.J. (1990). What are influences learning? A content analysis of revie w literature. The Journal of Educational Research, 84, 30-43.

[58] Wathen, T.E. (2010). Developing intentional engagement in adolescents: Volitional and metacognitive strategies use in the classroom. Thesis (Ed.D) - Talbot School of Theology, Biola University.

[59] Zhang, D., \& Goh, C. C. (2006). Strategy knowledge and perceived strategy use: Singaporean students' awareness of listening and speaking strategies. Language Awareness. 15 (3). http://dx.doi.org/10.2167/la342.0.

[60] Zohar, A., \& Dori, Y. (2012). Metacognition in science education: Trends in current research. Dordrecht: Springer. 


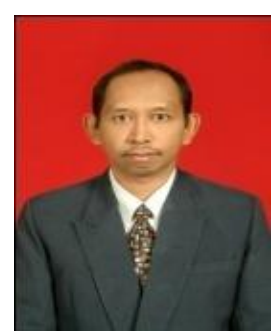

Sukris Sutiyatno was born in Solo, Central-Java Indonesia. He graduated his S1 English Department of Muhammadiyah University of Surakarta, S2 Master of Management of STIE Mitra Yogyakarta, S2 Applied Linguistics of Yogyakarta State University and S3 Technological Vocational Education of Yogyakarta State University, he was visiting scholar at Birmingham City University (BCU) UK 2011. He is a lecturer at STMIK Bina Patria Magelang, Central-Java, Indonesia.

His areas of interest are Linguistics, Management and Educational Management. He has published four books: 1. Kepemimpinan Pembelajaran dan Manajemen Kepuasan Siswa Instructional Leadership and Student's Satisfaction), 2. English for Information Technology, 3. English for Information Systems, 4. Metodologi Penelitian (Research Methodology), 5. Kepemimpinan Kepala Sekolah (School Leadership). Dr. Sutiyatno is lecturer and head of STMIK Bina Patria Magelang, Central Java, Indonesia.

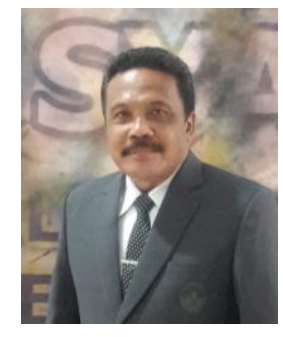

Sukarno, M. Si was born in Klaten Central-Java Indonesia. He graduated Strata 1 from English Department of Yogyakarta University, S2 post graduate of Universitas Indonesia (UI) Jakarta, and Doctorate degree (S3) from Semarang State University (UNNES). He was joining recharging program at the University of London and University of the Arts, London.

He has published many books; 1. Symbolism in Javanese Wedding 'Pranatacara' Genre; An Interpersonal Perspective, 2. Action Research; Basic Principles, concept and Its Implementation, 3.Introduction to Linguistics: A Literacy-Based Approach, 4. Cross-Cultural Understanding: A Literacy-Based Approach, 5. Sociolinguistics from the Teacher's Perspective. At this time, he is lecturer and Dean of Educational Faculty of UNTIDAR Magelang, Central Java Indonesia. 